\title{
EXTRATERRITORIAL CRIMINAL JURISDICTION AND THE NEW TURKISH PENAL CODE (2004.5237)
}

\section{Feridun YENISEY*}

\begin{abstract}
There is a "new" Turkish Penal Code (NTPC) to be effective on April $1^{s t}, 2005$. In this short paper, which has been prepared in memoriam of my dear friend Prof. Dr. Aslan Gündüz, we shall try to demonstrate the main principles of the "New Turkish Penal Code" in respect to its application ratione loci.
\end{abstract}

\section{Principles of international criminal law}

When reshaping its criminal law, a law-maker has to try to serve the goal of the creation of a peaceful, orderly world society, based on the rule of law and has also to acknowledge the existence of several units of jurisdiction, his duties of protection of individuals and their liberties living under his jurisdiction and the need of furtherance of international cooperation. However, Public International Law restricts the liberty of states to shape their criminal law. There are norms or principles that govern sustentative aspect of criminal law. There are also procedural standards to be observed in the application of criminal law. International law has some impacts on the state legislators when they determine the scope of application their laws. Public international law imposes also some limits on the right of the states to determine the scope of their criminal laws ratione loci.

These limitations are applied to all states equally and are not qualified as infringement on the sovereignty. Three traditional branches of state

${ }^{*}$ Prof. Dr., University of Bahçeşehir 
authority; (legislative jurisdiction, judicial jurisdiction and executive jurisdiction) are the basis for state sovereignty.

Limitations to the executive jurisdiction such as the exercise of executive jurisdiction (such as arrest, search, seizure or other coercive measures within the territory of another state) is not permitted under public international law, except with the consent of the state concerned, such as the "European arrest warrant".

However, there are some non-binding limitations to the legislative jurisdiction in the field of criminal law, such as "the primacy of the principle of territoriality", "recognition of equality of and mutual respect for the participants international intercourse", the "non-intervention principle" and "the rule of law principles".

The principles of the rule of law require that criminal law norms must be precise and recognizable to the individuals governed by this law. The principle "nullum crimen sine lege", "nullum poena sine lege" and "in dubio pro reo" have binding force under International Human Rights Instruments. ${ }^{2}$

The traditional bases of jurisdiction are; territoriality, protective, nationality, universality, and passive - personality principles. European law has expanded to cover extraterritorial crime, so long as there is some connection with the asserting state. For example, the New Turkish Penal Code (NTPR) provides for jurisdiction over extraterritorial crime when a Turkish citizen (Art. 11 NTPC) commits a crime abroad or the need to protect certain domestic (Art. 12 NTPC) or international (Art. 13 NTPC) legal interests. ${ }^{3}$

\section{Crimes committed within the Turkish territory}

\section{The Principle of Territoriality}

The New Turkish Criminal Code (Art. 8) adopts the principle of territoriality as a general rule, with few exceptions. In order not to let criminals go unpunished, a crime committed outside Turkish territory, by foreigners or against them, will be prosecuted (aut dedere aut judicare) and punished in accordance with the Turkish Criminal Code. 
According to Article 8(1) New Turkish Penal Code, whoever commits a crime in the territory of Turkey, shall be punished in accordance with Turkish Law.

A Turk sentenced in a foreign country for a crime that was committed in Turkish territory, shall be retried in Turkey (Art. 9 NTPC). A foreigner, who has been sentenced in a foreign country for a crime according to local legislation, shall be tried in Turkey upon the request of the Minister of Justice, if there is a connection to Turkish Law.

In terms of geography, the application of the New Turkish Penal Code reflects the system of territoriality as a basic rule. The land within the frontiers is considered a country's territory. The territorial application of criminal law comprises the rivers, lakes and the internal waters of the state. According to Act No. 2674 dated May 20, 1982, the internal waters of Turkey extend 6 Miles out to sea.

A criminal offense on board of a ship is considered committed in the territory of the state whose flag the ship flies, when the ship is in international waters. But warships are an exception and are considered to be in Turkish territory even if they are actually in international waters, or outside of the 6 Mile limit.

Sometimes a crime can be international, if it is committed in more than one state. The Court of Cassation has decided in one case when an airplane was hijacked from Bulgaria, that the crime was committed in the state where the act was committed.

The territorial principle allows jurisdiction over criminal conduct, providing that a material element of the crime or its effect occurs within the territorial boundaries of the state.

The objective territorial theory is the basis of jurisdiction when an effect of an offense impacts on the asserting state's territory. The subjective territorial theory is the basis of jurisdiction when an element of an offense occurs within the territory. The subjective territorial theory provides that a forum state will have jurisdiction over a homicide when the conduct within the forum state constitutes an attempt to commit homicide, even though the death occurs outside the state. 
Thus, a state could assert and approve jurisdiction over larceny by fraud, for example, even though the delivery and acceptance of the goods occurred outside the territory, as long as material element of the offense occurred within the territory from which the goods were sent (Art. 8(1) NTPC). Similarly, jurisdiction over a homicide is considered appropriate when the conduct within the forum state constitutes an attempt to commit the homicide, even though death occurs outside the state (Art. 8(1) NTPC).

The principle of ubiquity provides that a crime is deemed to have occurred in the place where the perpetrator acted or in the place where the statutorily proscribed harm occurred.

The new Turkish Penal Code applies the ubiquity principle. Where the acts of the crime has been "party" committed in a foreign country, or the outcome of the action that has been committed abroad, occurs within the Turkish territory, the crime shall be considered as a "crime committed in Turkey" under Art. 8/1 NTPC. There is also a list of grave crimes in Article 13, where the crimes committed outside of Turkish territory shall be prosecuted in Turkey.

\section{Crimes committed in a foreign country}

\section{The "nationality" or "active personality principle"}

Crimes committed in the third states or crimes against or by nationals of the requesting state are the subject to the "Turkish international criminal law".

The state follows its citizens in foreign countries (Art. 11 NTPC) (personality principle). The Turkish State also punishes crimes committed abroad against its citizens (Art. 12(2) NTPC) and crimes committed against the Turkish State (Art. 12(1) NTPC).

In Turkish Criminal Law, the principle of nationality is not valid as a single rule. It is also supported by other principles. The nationality theory bases jurisdiction on the nationality of the perpetrator of the offenses as proscribed by the state of his allegiance, no matter where the offense takes place. Turkish law applies a broad active personality principle. Nationality is a link so strong that the state may prosecute any of its nationals for offenses they commit anywhere in the world, so long as the offense is 
punishable in the place where, it was committed (NTPC 19/1). This theory underlies the importance of the state maintaining its sovereignty over each national and in maintaining its respect internationally by punishing its own wrongdoers.

Article 11 of the new Turkish Penal Code regulates "offences committed by Turkish nationals" in a foreign country: A Turkish citizen, who commits an offence in a foreign country, shall be punished in Turkey according the Turkish Criminal Statutes. There is an official and mandatory prosecution if the offence requires an imprisonment at the lover level not less than one year according to Turkish Law.

There are three requirements attached to this prosecution: a) the perpetrator must be in Turkish territory, b) there must be no judgment rendered against him in the foreign country, c) the offence must be a "prosecutable" offence in Turkey (Art. 11(1) NTPC).

If the offence requires a punishment at the lover lever less than one year, then the adjudication depends on the complaint (şikayet) of the victim who suffered harm, or of the foreign government. This complaint must have been filed within six months after the perpetrator who is a Turkish citizen had entered Turkish territory (Art. 11(2) NTPC).

The gravity of the punishment constitutes "a condition for investigation" (sorușturma koşulu) in such cases. The amount of the punishment shall be calculated during the preliminary investigation (sorussturma evresi) taking in account of the lover level of the alleged aggravating factors and the upper level of the alleged mitigating factors (Art. 15 NTPC).

\section{Passive Personality Principle}

The passive personality principle grants a state the authority to prosecute and punish perpetrators of a criminal conduct that harms or is intended to harm a Turkish citizen. The Turkish Penal Code extends the application of Turkish Criminal Law to offenses committed extraterritorially against Turkish nationals.

If a foreigner commits a crime that entails at least one year imprisonment against a Turkish citizen or against a legal person of private law which is established according Turkish Laws, shall be punished in accordance with 
the Turkish Penal Code, a) if the offender is present in Turkey, b) if there has been no judgment rendered against him in the foreign country, and if the victim, who suffered losses has filed a "complaint" (şikayet) (Art. 12(2) NTPC).

\section{The Protective Principle}

This principle is relevant when an extraterritorial offense has an effect on, or pose a danger to the security, interest, integrity, sovereignty, treasury, or other important governmental functions of a state.

A foreigner who commits a crime in a foreign country other than one mentioned in Article 13 against the interest of (zararina) Turkey, entailing imprisonment for a minimum period of one year under Turkish Law, shall be punished in accordance with the Turkish Penal Code, if the offender is present in Turkey (Art. 12(1) NTPC). The adjudication depends on the request (istem) of the Minister of Justice (Art. 12(1) NTPC).

The focus of this principle is the nature of the interest that is injured, rather than the place where the harm occurs. The basic premise of Turkey's protective principle is that the state will subject "offenses committed abroad by foreigners (as well as by citizens) to its punitive power if thereby domestic interests are endangered or violated".

The protective principle in Turkey also obtains jurisdiction over conduct impacting or threatening impact on other important public interests.

\section{The Principle of Vicarious Administration of Justice}

The principle of the vicarious administration of justice, which provides that if a state refuses to extradite an individual; that state shall prosecute him as long as the conduct involved serious and punishable behavior in the state in which the conduct occurred.

The desire to find solidarity among nations attempting to combat international and transnational crime suggests that if Turkey refuses to extradite a person who has committed an offense against the law of a foreign requesting state, Turkey ought to prosecute that person if the conduct committed constituted a crime under Turkish law. 
Vicarious administration of justice is common in Europe and has been adopted in several extradition treaties, although it is difficult accepting jurisdiction based solely on the basis of a refusal to extradite. If a foreigner commits a crime against a foreigner in the foreign country, the perpetrator shall be tried in Turkey under the following requirements (Art. 12(3) NTPC): a) The crime must entail imprisonment of not less than three years according to Turkish Laws, and b) There must be no extradition treaty between Turkey and that respected country, or the request for extradition has not been approved by the country of nationality.

A foreigner, who has committed a crime that falls under Article 12(1) of the New Turkish Penal Code shall be retried in Turkey, if the Minister of Justice files a request (istem), even if the perpetrator had been convicted by a foreign court, or the prosecution against him or his punishment was dropped for any reason, was acquitted or the committed crime was a not prosecutable offence any longer.

\section{The Universality Principle.}

The European view of the universality principle creates a "genuine link" for a given state to create extraterritorial jurisdiction based on international treaties that, for the most part, oblige each member state to do so.

International Conventions and custom provide that several crimes trigger universal jurisdiction. These include piracy, slave trade, war crimes, crimes against humanity, hijacking and sabotage of civil aircraft, genocide, and apartheid.

The New Turkish Penal Code has taken account of this development (NTPC 13/1a and c-i): Turkish Penal Code (Article 13/1, b) lays down the "principle of self protection". The crimes listed below if they are committed in a foreign country by a Turkish citizen or a foreigner, are subject to Turkish criminal law: crimes which are regulated in the first book, first chapter of the Criminal Code; crimes which are listed in second book, fourth chapter 3, 4, 5, 6, 7 and 8 sections, torture (Article 94, 95), intentional pollution of environment Article 181, production and trafficking in narcotics or inhibiting substances (Article 188), facilitating the use of narcotics or inhibiting substances (Article 190), forgery in money (Article 197), production and trafficking in tools that are used in production of money and valuable stamps (klymetli damga) (Article 200), forgery in seals 
(Article 202), prostitution (Article 227), bribery (Article 252), hijacking or tempering of sea, rail road or air transportation vessels.

Even if the crimes mentioned in the first paragraph of Article 13, subsection (a) and (b) has been tried and convicted or acquitted in a foreign country, there shall be a new trail in Turkey upon the order (talep) of the Minister of Justice.

\section{Extradition}

The Republic of Turkey does not extradite its citizens under Article 38 of the Constitution, except the obligations required by the ICC Statute (Art. 18/2 NTPC). Therefore, if a citizen commits a crime outside of Turkey he will be tried in Turkey (Art. 11 NTPC). But the act committed outside of Turkey should be regarded as a crime according to the Turkish Law. If the act is a crime in Turkey, but not in the place where the act was committed, the perpetrator can not be punished in Turkey (Art. 19 NTPC). On the other hand, the accused must be present in Turkey. If a Turkish citizen commits a crime outside Turkey, he will be automatically prosecuted by the Public Prosecutor if the crime requires imprisonment for more then one year. If the upper level of imprisonment is less then one year, the initiation of prosecution may be upon the complaint of the damaged party or the foreign Government (Art. 11 NTPC).

If a foreign State requests extradition of a foreigner, the Court determines the citizenship of the requested person and the nature of the felony committed. If the crime does not constitute a crime under Turkish criminal Codes, or is related to the freedom of speech (düşünce suçu), is of a political or military nature, has been committed against the security of the Republic of Turkey, or has been committed against a Turkish citizen or against a legal entity that has been established according the Turkish Laws, or the crime does not fall under the jurisdiction of the Turkish State, or the statute of limitations of that crime has expired or there has been an amnesty, extradition cannot be granted (NTPC 18/1).

In cases where there are strong suspicions that the individual, in case if extradited, would have been prosecuted or punished because of his affiliation to a ethnical, religious, citizenship, social group or because of his political views, or would be subject to torture or maltreatment, the request for extradition shall not be admitted (Art. 18/3 NTPC). 
The Court of Assizes where the related individual resides has jurisdiction to decide upon the request of extradition, applying the provisions of NTPC Art. 18, and according the provisions of the International Conventions. The decision may be appealed to the Court of Cassation (Yargitay) (Art. 18/4 NTPC).

The decision of the court not to extradite is final and the Government has no discretion at this case. If it is determined that the requested person is a foreigner and that his felony is of an ordinary nature, the Government may accept the request. If the request is accepted, a warrant of arrest against the requested person may be issued (Art. 18/7 NTPC).

The Republic of Turkey is part of the European Convention of Extradition. There should be at least one year of imprisonment according to the Law of the requesting State. This time limit considers the upper scale of the foreseen punishment.

In case that the individual has been extradited, he can only be tried or the punishment may be executed on the basis of the crimes which has been indicated in the extradition order (Art. 18/8 NTPC).

\section{Limits of the punishment in crimes committed abroad: taking into consideration of a Foreign Criminal Code (Art. 19 NTPC).}

In Turkish Criminal Law, crimes committed outside of Turkey have become a special category. The development in this field began in 1965 . Article 18/1 of the Code on Enforcement of Punishments had ruled that a foreigner who had been sentenced in Turkey is liable to serve his sentence in his country, if the principle of reciprocity and the execution of the full sentence is guaranteed.

In 1984, Act No. 3002 has abolished the above-mentioned regulation and substituted it with a larger Act: the sentences of the foreign countries are applicable for prosecutions in Turkey. For this purpose there is a procedure, which is contained in the Act: the factual findings of the foreign judgment are considered as final. Upon this, the Turkish Court crafts a new Turkish Judgment and declares the punishment, which shall be executed in Turkey. However, the final punishment cannot be more severe than the punishment of the foreign judgment. Foreigners who have committed crimes in Turkey 
and have been sentenced by a Turkish Court can be imprisoned in their own countries under the condition of reciprocity.

The development in this field has continued. In 1991, Article 10a had been added to the Turkish Penal Code. Article 10a was taken from the Draft Penal Code of 1989. The New Turkish Criminal Code recently amended Article 10a. According to this regulation, if a Turkish citizen or a foreigner had committed a crime in a foreign country and was subject to Turkish Criminal Jurisdiction, according the regulations of the First Book, Part I of the Turkish Criminal Code, then the application of law which favors the accused was obligatory. The Turkish Judge had to choose the milder statute between the Turkish Code and the code of the place of commitment. The provisions of Article 10a of the Penal Code did not apply to crimes, which have been committed against and have damaged the Republic of Turkey. The second exception held, that if the Code of the place of commitment is against Turkish public order or against the international obligations of Turkey, this Code was not be applicable in Turkey. In article 10a, the word 'public order' meaned the basic principles of the Turkish procedural law and the basic principles of Turkish Criminal Law. For example, if a principle of Islamic Law was in favor of the accused, this rule did no apply in Turkey.

The New Turkish Penal Code (2004.5237 Art. 19) has simplified the regulation: "In cases where there is an adjudication in Turkey for crimes which are committed outside of territory of the Republic of Turkey, the sentence shall be determined according to the Turkish Criminal Code and shall not accede the upper level of the punishment, which has been foreseen by the Criminal Code of the country where the crime has been committed (Art. 19/1 NTPC). This provision does not apply in crimes committed against the security or in the disadvantage of the Republic of Turkey, or in crimes committed against a Turkish citizen or against a legal person that has been established according to Turkish Law (Art. 19/2 NTPC). 


\section{Relevant Provisions of the New Turkish Penal Code:}

\section{Territorial Application}

Articel 8 - (1) Crimes committed within the territory of Turkey are subject to the application of Turkish criminal law statutes. In cases, where the acts has been committed partly or as a whole within the Turkish territory, or the outcome of the action has been occured within the territory of Turkey, the crime shall be considered as a crime committed within Turkish territory.

(2) Following crimes shall also be considered as a crime committer within Turkish territory:

a) Crimes committed in Turkish land-, and air-space and in Turkish territorial waters,

b) Crimes committed in high sea and in the airspace above it, crimes committed in Turkish sea and air vessels or crimes committed through them, which are there,

c) crimes committed in Turkish sea- and air vessels or crimes committed through them,

d) crimes committed in fixed platforms in Turkey's subsoil of the coast established in designated economic area, or against these establishments.

\section{Validity of foreign judgments}

Article 9- (1) If someone has been tried in a foreign country and there has been a judgemend rendered in that case, he shall be subject to a trial in Turkey, if the crime has been committed within the territory of Turkey.

\section{Crimes related to the office}

Article 10 - (1) Whoever performs an official duty in the name of Turkey in a foreign country and commits a crime that is related to this office, shall be retried in Turkey, even if he has been tried and convicted in that foreign country

\section{Crimes committed by Turkish citizens.}

Article 11 - (1) If a Turkish student commits a crime in a foreign country which entails imprisonment at the lower level not less then one year according to Turkish criminal laws and in cases where he is present in Turkey and there has been no judgement rendered against him according to this crime and the act is prosecutable in Turkey, shall be punished according to the Turkish criminal laws.

(2) In cases where the crime requires imprisonment at the lower level less than one year, the adjudication is depending on the complaint of the victim who suffert a loss or the foreign government. In such cases the complaint must be filed within six months after the citizen has entered Turkish territory. 


\section{Crimes committed by foreigners}

Article 12 - (1) A foreigner who commits a crime in a foreign country other than one mentioned in Article 13 against Turkey, entailing imprisonment for a minimum period of one year under Turkish Law, shall be punished in accordance with the Turkish Penal Code, if the offender is present in Turkey (Art. 12(1) NTPC). The adjudication depends on the request (istem) of the Minister of Justice (Art. 12(1) NTPC).

(2) If a foreigner commits the above mentioned crime against a Turkish citizen or against a legal person of private law which is established according Turkish Laws, shall be punished in accordance with the Turkish Penal Code, a) if the offender is present in Turkey, b) if there has been no judgemend rendered against him in the foreign country, and if the victim, who suffered losses has filed a "complaint" (sikayet) (Art. 12(2) NTPC).

(3) If a foreigner commits a crime against a foreigner in the foreign country, the perpetrator shall be tried in Turkey under the following requirements (Art. 12(3) NTPC):

a) The crime must entail imprisonment of not less than three years according to Turkish Laws.

b) There must be no extradition treaty between Turkey and that respected country, or the request for extradition has not been approved by the country of nationality.

(4) A foreigner, who has committed a crime that falls under Article 12(1) of the New Turkish Penal Code shall be retried in Turkey, if the Minister of Justice files a request (istem), even if the perpetrator had been convicted by a foreign court, or the prosecution against him or his punishment was dropped for any reason, was acquitted or the committed crime was a not prosecutable offence any longer.

\section{Other crimes}

Article 13 - (1) The following crimes if they are committed in a foreign country by a Turkish citizen or a foreigner, shall apply Turkish criminal law:

a) The crimes which are listed in the first book, first chapter,

b) Crimes which are listed in second book, fourth chapter $3,4,5,6,7$ and 8 sections.

c) Torture (Article 94, 95),

d) Intentional pollution of environment Article 181,

e) Production and trafficking in narcotics or inhibiting substances (Article 188), facilitating the use of narcotics or inhibiting substances (Article 190) 
f) Forgery in money (Article 197), production and trafficking in tools that are used in production of money and valuable stamps (kiymetli damga) (Article 200), forgery in seals (Article 202),

g) Prostitution (article 227),

h) Bribery (Article 252),

i) Hijacking or tempering of sea, rail road or air transportation vessels

(2) Even if the crimes mentioned in the first paragraph, subsection (a) and (b) has been convicted or acquitted in a foreign country, there shall be a new trail in Turkey upon the order (talep) of the minister of justice.

\section{Investigation in cases of alternative punishments}

Article 14 - (1) In cases indicated in Article 11 and 12 there shall be know investigation or prosecution if the punishment of the investigated crime and tails the alternative application of imprisonment or judicial fine in the statute that describes the investigated crime.

Estimation of the punishment, which is the pre-condition of the investigation in Turkey

Article 15 - In cases, where the amount of the punishment is a pre-condition of starting an investigation in Turkey, the punishment shall be estimated at the phase of preliminary investigation while regarding the alleged legal aggravating factors at the lover level, and the legal mitigating factors at the highest level.

\section{Subtraction from sentence}

Article 16 - Wherever the crime has been committed, the period, which has been spent in a foreign country in police custody (gözaltında), under medical inspection in a clinic (gözlem), in remand (tutuklulukta) or in a correction center as inmate, shall be subtracted from the punishment to be inflicted on that person for the same offence.

\section{Deprivation of rights}

Article 17 - In cases explained in the above Articles, if the judgment of a foreign country is not contradicting Turkish Legal System requires a deprivation of rights according to Turkish Law, the court shall order upon the request of the Public prosecutor, that the consequences of that judgment shall be effective in Turkey.

\section{Extradition}

Article 18 - (1) A foreigner who allegedly committed or has committed a crime in a foreign country and there is a pending prosecution or a conviction rendered against him, may be extradited upon request in order to conduct a prosecution or to 
execute the sentence. However, in the following cases the request shall not be granted, if the act (fiil) which is the ground of the request of extradition;

a) is not a crime under Turkish Criminal Laws,

b) is a crime of freedom of expression (düşünce suçu) or has the character of a political of military offence,

c) has been committed against the security of Turkish State, or has inflicted harm to Turkish State, or to a Turkish citizen or to a legal person which has been established according Turkish Laws,

d) is a crime on which the Turkish State has jurisdiction,

e) the statute of limitation has expired or there has been an amnesty for this act.

(2) Except the obligations which are attached to the acquisition to the International Criminal Court Statute, a citizen shall not be extradited to a foreign country.

(3) The request on extradition shall be rejected in cases where there are strong grounds to suspect that in case of an extradition the individual might be prosecuted or punished or be subject to torture or male treatment (kötü muamele) on the grounds of his race, religion, citizenship, affiliation to a certain social group his political opinions.

(4) The decision on the extradition request shall be rendered by the Court of Assizes where the individual is present at that time (bulunduğu yer) under the provisions of this Article and under the provisions of international Conventions, which Turkey is a party of.

(5) Where the court decides that the extradition request is acceptable, the Council Ministers has discretion to put in force this decision.

(6) On the basis of the international Conventions of which Turkey is a party of, there may be decisions of protective measures (koruma tedbirleri) rendered against the individual, whose extradition has been requested.

(7) If the court decides that the extradition request is acceptable, additionally a decision to put the individual in custody in remand (tutuklama), or to apply other measures of proteqtion may be rendered, on the basis of the Criminal Procedure Code.

(8) If extradited, the individual may only be adjudicated under the offence, which has been the basis of the decision of extradition or the punishment may be executed as mentioned in the decision of extradition. 


\section{Taking into consideration the punishment in a foreign Criminal Code}

Article 19 - (1) The punishment to be inflicted according to the Turkish Criminal Code shall not exceed the upper level of the punishment as foreseen in the Criminal Code of a foreign country, where the crime has been committed outside of Turkish territory and there is a adjudication in Turkey because of this crime.

(2) However; if the crime has been committed

a) against the security of Turkey or Turkey had suffered losses,

b) against a Turkish citizen or a legal entity established according Turkish Laws had suffered losses, the provisions of subsection (1) does not apply:

\section{Endnotes}

${ }^{1}$ Extraterritorial criminal jurisdiction, Council of Europe, Legal Affairs, Strasbourg 1990 , p. 21.

2 In Europe there is a distinction between substantive and procedural law. Substantive law concerns the contents of rights and duties of the state as the public power or of the individual. Procedural law, however, regulates the manner in which these rights can be realized by means of judicial decisions.

${ }^{3}$ Selected Bibliography:

Bayraktar, Siyasal Suç, (Istanbul 1982).

Donay, "Suçluların İadesinde Yeni Gelismeler", ÜHFM 1984, p. 241.

Eser/Lagodny, Principles and Procedures for a New Transnational Law, Eigenverlag Max-Planck-Institut für ausl. u. int. StR., Freiburg i.Br., 1992.

İçel and Donay, Karsılastırmalı ve Uygulamalı Ceza Hukuku, 2. Bası, (Filiz, Istanbul 1993).

Özgen, Suçluların Geri Verilmesi, (Ankara 1962).

Tezcan, 'Ceza Kanununun Yer Itibariyle Uygulanması: Milletlerarası Ceza Hukuku, in, Ceza Hukuku El Kitab1, (Beta, Istanbul 1989).

Yenisey, "Auslaendische Strafmasse im turkischen Strafrecht", in, Informationsbrief Auslaenderrecht 1994/1, p.9.

Yenisey, "die Rechtliche Stellung des im Ausland straffaellig gewordenen Turken in der Turkei”, Informationasbrief Auslaenderrecht, Heft 4, April 1988, s. 125.

Yenisey, Milletlerarası Ceza Hukuku: Ceza Yargılarının Milletlerarası Değeri ve Mevzuat, (Beta, İstanbul 1988), p. 225. 